\title{
ANALISIS PELAFALAN BUNYI SEGMENTAL PADA SISWA TUNARUNGU SMPLB B SLBN 7 JAKARTA
}

\author{
Riski Mareta \\ SMPLB B SLBN 7 Jakarta \\ riskimareta@gmail.com
}

\begin{abstract}
ABSTRAK
Penelitian bertujuan untuk memperoleh informasi mengenai bunyi segmental yang berupa bunyi vokal, bunyi konsonan, bunyi diftong, dan kluster. Penelitian ini dilakukan pada tiga orang siswa tunarungu Sekolah Menengah Pertama Luar Biasa B (Tunarungu) SLBN B 7 Jakarta. Penelitian ini dilaksanakan pada tahun ajaran 2018/2019. Metode yang digunakan dalam penelitian ini adalah deskriptif kualitatif dengan teknik analisis data. Data diperoleh dengan cara pengamatan dan wawancara secara langsung untuk mengambil data ujaran lisan yang kemudian ditranskripsi ke dalam lambang fonetik. Berdasarkan hasil analisis pada data ujaran lisan seorang siswa, ditemukan data sebanyak 178 bunyi vokal, serta sebanyak 143 bunyi konsonan, 2 bunyi kluster yang dihasilkan dan 149 pola silabel yang ditemukan, dan berdasarkan hasil analisis ini siswa tidak menghasilkan bunyi diftong.Jadi, dapat disimpulkan bahwa terdapat 464 data secara keseluruhan pada penelitian ini dari tiga orang siswa tunarungu SMPLB B SLBN 7 Jakarta. Implikasi terhadap pembelajaran Bahasa Indonesia, yaitu meningkatkan keterampilan berbicara pada siswa tunarungu. Dengan demikian, siswa dapat melatih keterampilan berbicaranya melalui pengajaran bahasa Indonesia dan menghasilkan bunyi ujaran lisan yang termasuk ke dalam bunyi segmental.
\end{abstract}

Kata kunci: pelafalan, bunyi segmental, siswa tunarungu 


\title{
SEGMENTAL SOUND BALANCE ANALYSIS IN DEAF STUDENTS IN SMPLB B SLBN 7 JAKARTA
}

\begin{abstract}
The study aims to obtain information about segmental sounds in the form of vocal sounds, consonant sounds, diphthong sounds, and clusters. This study was conducted on three deaf students SMPLB B SLBN 7 Jakarta. The method used in this study is descriptive qualitative with data analysis techniques. Data is obtained by direct observation and interviews to retrieve oral speech data which are then transcribed into phonetic symbols. Based on the results of analysis on the verbal speech data of a student, it was found 178 vowel sounds, and 143 consonant sounds, 2 cluster sounds produced and 149 syllable patterns found, and based on the results of this analysis students did not produce diphthong sounds. So, it can be concluded that there were 464 data in total in this study out of three deaf students tunarungu SMPLB B SLBN 7 Jakarta. Implications for Indonesian language learning, namely improving speaking skills in deaf students. Thus, students can practice their speaking skills through teaching Indonesian and produce oral speech that is included in segmental sounds.
\end{abstract}

Keywords: pronunciation, segmental sound, deaf students

\section{PENDAHULUAN}

Salah satu kunci sukses dalam berkomunikasi dengan menggunakan bahasa adalah ketepatan berbahasa. Penggunaan bahasa yang tidak teratur akan menyulitkan pembaca atau pendengar untuk dapat memahaminya. Ketepatan dan keteraturan dalam berbahasa memerlukan pengetahuan dan pemahaman yang luas dan mendalam mengenai linguistik.

Penggunaan bahasa yang benar dapat membantu pendengar memahami maksud yang diujarkan. Salah satunya adalah pelafalan yang benar, ciri menonjol yang menyangkut lafal, adalah bahwa sistem bunyinya lebih kompleks (Chaer, 2013).

AKSIS Jurnal Pendidikan Bahasa dan Sastra Indonesia

Volume 2 Nomor 2, Desember 2018 e-ISSN: 2580-9040

e-Journal: http://doi.org/10.21009/AKSIS 
Pelafalan baku ini mempunyai khasanah bunyi yang lebih banyak, pelafalan baku juga mempunyai kaidah fonotaktis yang lebih rumit (Hildayani, 2008). Selain khasanah bunyi yang lebih banyak dan kaidah fonotaktis yang menyatakan kombinasi-kombinasi bunyi yang lebih kompleks, pelafalan baku cenderung berbeda dengan pelafalan tidak baku.

Dalam hal kaidah pemberian tekanan pada kata, pelafalan baku cenderung memperlihatkan kaidah tekanan yang lebih teratur dan lebih berdasar daripada pelafalan tidak baku. Perbedaan lafal akibat perbedaan kaidah penempatan tekanan antara penutur akan lebih tajam bila kata-kata itu berada dalam untaian kalimat (Indriati, 2011). Pada umumnya aspek-aspek bunyi dan tekanan yang membedakan ragam bahasa baku dengan ragam bahasa tidak baku bersumber pada perbedaan sistem bunyi bahasa Indonesia. Menurut Parera (1983) kemampuan mengucapkan bunyi-bunyi artikulasi atau kata-kata untuk mengekspresikan, mengatakan, serta menyampaikan pikiran, gagasan, dan perasaan disebut dengan berbicara.Secara umun pendengar menerima informasi melalui rangkaian nada, tekanan, dan penempatan.

Pelafalan adalah tata cara pengucapan kata, dalam sistem bunyi ujar dapat dipelajari dari dua sudut pandang. Pertama, yaitu bunyi-bunyi ujar yang dikenal sebagai bagian dari suatu sistem bahasa yang lazim disebut dengan fonemik. Sedangkan bunyibunyi ujar yang dipandang sebagai media bahasa semata dan sangat berkaitan erat dengan bagaimana manusia berbahasa, mendengar dan memproses ujaran yang diterima disebut dengan fonetik (Muslich, 2009).

Dalam fonologi bunyi ujaran atau fonetik yang dihasilkan oleh alat ucap manusia mempunyai jumlah yang tidak terbatas. Bunyi-bunyi tersebut berbeda 
kualitasnya akibat perbedaan anatomi manusia. Bunyi tersebut dapat digolongkan menjadi bunyi tidak disertai hambatan arus udara pada alat bicara yang disebut bunyi vokal dan bunyi yang dibentuk dengan menghambat arus udara pada alat berbicara yang disebut konsonan.

Bahasa pada dasarnya memiliki akar kelisanan yang kuat, dari fakta tersebut ditunjukan bahwa sesungguhnya bahasa Indonesia dirancang dengan dasar-dasar kelisanan yang kental. Kajian tata bahasa untuk bahasa lisan khususnya bahasa yang memang tidak mengenal tradisi tulis adalah tidak tepat apabila tidak memfokuskan kajian pada aspek-aspek kelisanan bahasa itu (Utami, 2017). Esensi bahasa lisan adalah gejala akustik, baik dalam tataran bunyi maupun tataran yang lebih tinggi. Bahasa lisan dipandang sebagai gejala akustik yang merupakan realisasi aspek semantis sebuah bahasa.Oleh karena itu, mengkaji bahasa lisan haruslah bertumpu pada maujud akustik bahasa itu, tanpa mengabaikan ciri semantis bentuk-bentuk tuturan yang dikaji. Realisasi tulis bahasa tidak lebih dari penuangan bahasa lisan dalam sistem simbol visual, bagaimanapun simbol visual itu berkorespondensi dengan gejala-gejala akustik dalam bahasa lisan.

Bahasa lisan cenderung bersifat natural dan tak formal yang menunjukan kelisanan yang begitu nyata.Bahasa lisan tidak ada petunjuk atau aturan yang jelas, itulah sebabnya bahasa lisan cenderung melambangkan aspek-aspek kelisanan bahasa.Kajian aspek fonetis memegang peranan penting terhadap bahasa lisan. Bahkan, kajian bahasa lisan diidentikan dengan kajian fonetik, yang dikaitkan dengan hakikat kelisanan sebuah bahasa, kajian fonetik memang bunyi-bunyi bahasa, baik realisasi 
akustik, alat dan cara mengartikulasikan bunyi, maupun cara mempersepsi bunyi-bunyi tersebut.

Terdapat beberapa contoh suku kata tertutup dan suku kata terbuka, suku kata tertutup akan ada huruf vokal yang diikuti huruf konsonan, sedangkan suku kata terbuka adalah suku kata yang diakhiri oleh huruf vokal, misalnya kata [makan] dua suku kata $=\mathbf{m a}-\mathbf{k a n}$, pola suku kata VK. Suku kata ma merupakan suku kata terbuka karena diakhiri oleh huruf vokal, sedangkan suku kata kan merupakan suku kata tertutup karena diakhiri oleh bunyi konsonan dan bunyi vokal yang pendek. Begitupun dengan kata [hakam] dua suku kata = ha $-\mathbf{k a m}$, pola suku kata VK, ha merupakan suku kata terbuka dan kam merupakan suku kata tertutup.

Selain pelafalan bunyi vokal dan beberapa suku kata tertutup dan terbuka, ada juga pelafalan bunyi konsonan terjadi setelah arus udara melewati pita suara yang terbuka sedikit atau agak lebar. Bunyi tersebut akan diteruskan ke rongga mulut atau rongga hidung dengan mendapatkan hambatan di tempat artikulasi tertentu. Bunyi konsosnan dapat diklasifikasikan berdasarkan (1) tempat artikulasi, (2) cara artikulasi), (3) bergetar tidaknya pita suara, (4) striktur. Jika terdapat dua buah konsonan dalam satu silabel yang beruntun disebut dengan gugus konsonan atau kluster.

Selain bunyi konsonan contoh ujaran di atas juga mengandung bunyi vokal, bunyi vokal adalah jenis bunyi bahasa yang ketika dihasilkan atau diproduksi, setelah arus ujar keluar dari glotis tidak mendapat hambatan dari alat ucap, melainkan hanya diganggu oleh posisi lidah baik vertikal maupun horisontal, dan bentuk mulut. Kemudian ada bunyi diftong, bunyi diftong berkaitan dengan dua buah vokal yang merupakan satu bunyi dalam satu silabel, contohnya diftong [ai] pada kata 
[gulai].Diftong ini dilafalkan dengan posisi lidah menjadi lebih tinggi daripada yang pertama, dengan begitu diftong [ai] diklasifikasikan menjadi diftong naik. Dari beberapa bunyi-bunyi diatas, bunyi tersebut dapat disebut atau diklasifikasikan menjadi bunyi segmental, karena bunyi tersebut dapat disegmentasikan.

Berkaitan dengan hal tersebut penggunaan bahasa Indonesia yang baik dan benar menurut kaidah tata bahasa sepertinya belum terpenuhi, penggunaan bahasa Indonesia, secara lisan maupun tertulis yang berada diluar atau menyimpang dari faktor-faktor komunikasi dan kaidah kebahasaan dalam bahasa Indonesia.

Biasanya ketidaktepatan berbahasa dialami oleh anak yang menggunakan dua bahasa atau billingual. Namun juga bisa disebabkan oleh adanya ketidakmampuan berujar yang disebabkan oleh ketidaksempurnaan salah satu organ tubuh manusia, seperti yang terjadi pada penderita tunarungu yang tidak bisa mendengar secara utuh seperti apa bunyi itu dikeluarkan. Penderita tunarungu sendiri tidak dapat secara normal mendengar bunyi atau suara yang ada di dekat mereka. Banyak anak yang belum memenuhi syarat minimal untuk penggunaan bahasa baik kepentingan berkomunikasi umum di dalam sebuah masyarakat.Oleh sebab itu, pengkajian analisis pelafalan bunyi segemental pada siswa tunarungu ini merupakan suatu langkah yang lebih lanjut mengenai gangguan berbahasa, khususnya dalam bahasa Indonesia.

\section{METODE}

Penelitian ini bertujuan untuk untuk memperoleh deskripsi secara objektif tentang pelafalan bunyi segmental pada anak tunarungu. Apakah ujaran lisan yang

AKSIS Jurnal Pendidikan Bahasa dan Sastra Indonesia

Volume 2 Nomor 2, Desember 2018 e-ISSN: 2580-9040

e-Journal: http://doi.org/10.21009/AKSIS 
dihasilkan oleh siswa tunarungu ini berupa bunyi vokal, bunyi konsonan, bunyi diftong, bunyi kluster serta bunyi apa saja yang dapat dihasilkan dan tidak dapat dihasilkan oleh siswa tunarungu SMPLB B SLBN 7 Jakarta. Metode yang digunakan dalam penelitian ini adalah metode deskriptif kualitatif. Metode ini membatasi penelitian deskriptif sebagai penelitian yang menggambarkan keadaan subjek atau objek penelitian pada saat tertentu berdasarkan fakta-fakta yang apa adanya. Dalam penelitian ini, ujaran lisan siswa tunarungu dideskripsikan dan dianalisis berdasarkan rangkuman analisis yang diturunkan dari teori fonetik dan bunyi segmental bahasa Indonesia.Teknik yang digunakan dalam tahap penyediaan data untuk penelitian ini adalah pengamatan dan wawancara.

Penelitian ini menggunakan teknik wawancara pada 3siswa laki-laki di SMPLB B SLBN 7 Jakarta, dari hasil wawancara yang didapatkan bahwa penelitian ini memilih tiga siswa laki-laki sebagai sumber data penelitian secara random karena berdasarkan klasifikasi ketunarunguan ketiga siswa laki-laki tersebut berada pada klasifikasi tunarungu ringan, jadi suara atau ujaran lisan yang diperoleh akan terdengar lebih jelas.

Persepsi awal pada penelitian ini ialah bahwa siswa tunarungu tidak secara jelas mendengar bunyi-bunyi bahasa yaitu bunyi segmental yang terdiri dari bunyi vokal, bunyi konsonan, bunyi diftong, dan bunyi kluster, oleh sebab itu pada pelafalanya juga tidak secara jelas dikeluarkan bunyi-bunyi bahasa tersebut. Namun persepsi tersebut kurang mendukung karena mungkin saja siswa tunarungu tidak bisa melafalkan bunyi disebabkan oleh ketidaksempurnaan organ mendengar mereka, bukan karena kurangnya fungsi alat bicara mereka. Setiap mata pelajaran Bahasa Indonesia guru selalu melatih kemampuan berbicara siswa pada setiap proses pembelajaran maupun luar pembelajaran. Maka penelitian ini diputuskan pada saat proses pembelajaran bahasa 
Indonesia maupun pelajaran lainya, saat siswa secara aktif mengeluarkan ujaran-ujaran lisan baik pada saat berkomunikasi dengan guru mapun pada teman sekelasnya. Peneliti juga diizinkan mengamati proses pelafalan bunyi segmental yang dikeluarkan oleh siswa tunarungu SMPLB B SLBN 7 Jakarta pada bulan Januari sampai bulan Maret.Setelah mendapatkan siswa yang akan dijadikan sumber data penelitian, selanjutnya masuk ke dalam kelas guna melakukan observasi pelafalan bunyi segmental bahasa Indonesia dan melihat bunyi-bunyi apa saja yang dikeluarkan oleh siswa tunarungu. Pada penelitian ini peneliti terlibat secara langsung dalam peristiwa tutur yang dilakukan oleh siswa tunarungu, yaitu dengan bercakap-cakap atau berkomunikasi secara lisan dan tatap muka guna mendapatkan hasil uajaran siswa tunarungu. Peneliti juga mencatat hal-hal yang relevan, terutama bunyi-bunyi segmental apa saja yang dikeluarkan oleh siswa tunarungu.

Dalam penelitian ini, dilakukan teknik observasi secara langsung, guna pengambilan data ujaran pada saat pembelajaran Bahasa Indonesia oleh siswa jenjang SMPLB B dan memfokuskan penelitian pada pelafalan bunyi segmental pada siswa tunarungu SMPLB B SLBN 7 Jakarta.

\section{HASIL DAN PEMBAHASAN}

Data penelitian ini diperoleh dari transkripsi fonetik ujaran lisan pada siswa tunarungu. Berdasarkan data ditemukan pelafalan bunyi segmental pada siswa tunarungu, sebagai berikut: bunyi vokal, bunyi konsonan, bunyi diftong, bunyi kluster, dan silabel.

Pada bagian vokal terbagi menjadi bunyi $[\mathrm{a}],[\mathrm{i}],[\mathrm{u}],[\mathrm{e}],[\varepsilon],[ə],[\mathrm{o}]$, dan bunyi konsonan terbagi menjadi bunyi $[\mathrm{b}],[\mathrm{p}],[\mathrm{m}],[\mathrm{w}],[\mathrm{v}],[\mathrm{f}],[\mathrm{d}],[\mathrm{t}],[\mathrm{n}],[1],[\mathrm{y}],[\mathrm{r}],[\mathrm{z}]$, 
$[\tilde{\mathrm{n}}],[\mathrm{j}],[\mathrm{c}],[\mathrm{J}],[\mathrm{s}],[\mathrm{g}],[\mathrm{k}],[\mathrm{y}],[\mathrm{x}],[\mathrm{h}],[?]$, bunyi diftong terbagi menjadi bunyi [ai], [au], [oi], [əi], [ua], [uo], [uع], ,[ua], bunyi kluster terbagi menjadi bunyi [pl], [bl], [kl], [gl], [fl], [sl], [pr], [br], [dr], [tr], [kr], [gr], [fr], [sr], [ps], [ks], [dw], [sw], [kw], [sp], [sm], [sn], [sk], dan pola silabel terbagi menjadi pola V, KV, VK, KVK, KKV, KKVK, KVKK, KKKV, KKVKK, KKKVK, VKK. Berikut adalah data dan analisis pelafalan bunyi segmental pada siswa tunarungu:

\section{Analisis Vokal [a]}

\section{a. Posisi Awal}

Ujaran :[ahIr] (lahir)

Analisis:

Pada pelafalan [ahIr] pola silabelnyaV, KVK pada kata [a+hir].Bunyi vokal [a] yang dilafalkan pada posisi awal, merupakan vokoid belakang, rendah, tak bundar.Kata [ahIr] ini sebenarnya berbunyi lahir namun konsonan /1/ apikoaveolar, hambat, tak bersuara tersebut tidak muncul atau tidak dibunyikan.Jadi kata tersebut mengalami penghilangan bunyi konsonan /l/ sehingga yang muncul adalah vokoid /a/ di awal pelafalan.

\section{b. Posisi Tengah}

Ujaran :[hak] (gak)

Analisis:

Pada pelafalan [hak] pola silabel KVK, bunyi vokal /a/ dapat dilafalkan di posisi tengah dengan tepat yang merupakan vokoid belakang, rendah, tak bundar, kata [hak] ini 
sebenarnya berbunyi gaknamun konsonan /g/ digantikan dengan konsonan /h/. Jadi, kata tersebut mengalami penggantian bunyi konsonan /g/ sehingga yang muncul adalah konsonan $/ \mathrm{h} / \mathrm{atau}$ faringal di awal pelafalan.

\section{c. Posisi Akhir}

Ujaran :[iva] (Diva)

Analisis:

Pada pelafalan[iva] pola silabel V, KV, bunyi vokal /a/ dapat dilafalkan diposisi akhir dengan tepat yang merupakan vokoid belakang, rendah, tak bundar kata [iva] ini sebenarnya berbunyi Diva namun konsonan /d/ tidak muncul atau dibunyikan. Jadi, kata tersebut mengalami penghilangan bunyi konsonan /d/ sehingga yang muncul adalah vokal /a/ di awal pelafalan.

\section{Analisis Konsonan [b]}

\section{a. Posisi Awal}

Ujaran :[bəas] (belas)

Analisis:

Pada pelafalan [bəas] siswa dapat melafalkan bunyi [b] bilabial, hambat, tak bersuara dengan tepat, dan berpola silabel $\mathrm{KV}$, kata ini sebenarnya berbunyibəlas, namun konsonan /l/ tidak muncul atau tidak dibunyikan. Jadi kata ini mengalami penghilangan bunyi konsonan /1/ sehingga hanya muncul kata bəas pada pelafalanya.

AKSIS Jurnal Pendidikan Bahasa dan Sastra Indonesia

Volume 2 Nomor 2, Desember 2018 e-ISSN: 2580-9040 


\section{Analisis Konsonan [m]}

\section{a. Posisi Tengah}

Ujaran : [lima] (lima)

Analisis:

Pada pelafalan [lima] siswa dapat melafalkan bunyi konsonan $/ \mathrm{m} /$ pada posisi tengah dengan tepat, dan berpola silabel KV pada suku katakedua [ma] bunyi konsonan $/ \mathrm{m} /$ merupakan bunyi bilabial, nasal. Jadi, siswa dapat melafalkan kata lima dengan baik karena tidak ada penghilangan dan penggantian bunyi pada pelafalanya.

\section{Analisis Konsonan [s]}

\section{a. Posisi Akhir}

Ujaran :[bəas] (bəas)

Analisis:

Pada pelafalan [bəas] siswa dapat bunyi [s] lamino alveolar, frikatif, tak bersuara pada posisi akhir dengan tepat.Pola silabelnya VK pada kata [bə+as] karena pada suku kata kedua merupakan urutan bunyi vokal konsonan.Kata ini sebenarnya berbunyi belasnamun konsonan /1/ tidak muncul.Jadi, kata ini mengalami penghilangan bunyi konsonan /1/ sehingga hanya ada pelafalan bəas pada pelafalanya. 


\section{Rekapitulasi Bunyi Segmental}

Berdasarkan data yang diperoleh, berikut ini disajikan rekapitulasi pelafalan bunyi segmental secara keseluruhan yang dihasilkan oleh anak tunarungu.

Tabel Rekapitulasi Pelafalan Bunyi Segmental Siswa Tunarungu

\begin{tabular}{|c|c|c|c|c|c|c|}
\hline \multirow{2}{*}{ No. } & \multicolumn{4}{|c|}{ Bunyi Segmental } & \multirow{2}{*}{ Silabel } & \multirow{2}{*}{ Jumlah } \\
\cline { 2 - 5 } & Vokal & Konsonan & Diftong & Kluster & \\
\hline 1. & 170 & 143 & 0 & 2 & 149 & \multirow{2}{*}{ Jumlah Keseluruhan Bunyi Vokal } \\
\hline \multicolumn{7}{|c|}{} \\
\hline
\end{tabular}

Berdasarkan tabel rekapitulasi bunyi segmental diatas terdapat jumlah data bunyi vokal [a], [i], [u], [e], [ع], [ə], [o]yang dihasilkan sebanyak 170 dari keseluruhan data yang dihasilkan oleh siswa tunarungu, jumlah data bunyi konsonan $[\mathrm{b}],[\mathrm{p}],[\mathrm{m}]$, $[\mathrm{w}],[\mathrm{v}],[\mathrm{f}],[\mathrm{d}],[\mathrm{t}],[\mathrm{n}],[\mathrm{l}],[\mathrm{y}],[\mathrm{r}],[\mathrm{z}],[\tilde{\mathrm{n}}],[\mathrm{j}],[\mathrm{c}],[\mathrm{S}],[\mathrm{s}],[\mathrm{g}],[\mathrm{k}],[\mathrm{y}],[\mathrm{x}],[\mathrm{h}],[?]$ yang dihasilkan sebanyak 143 dari keseluruhan data yang dihasilkan oleh siswa tunarungu data, jumlah data bunyi diftong [ai], [au], [oi], [əi], [ua], [uo], [ue] ,[ua] tidak dihasilkan pada ujaran lisan siswa tunarungu oleh sebab itu rekapitulasi data diftong hanya 0 , jumlah data bunyi kluster [pl], [bl], [kl], [gl], [fl], [sl], [pr], [br], [dr], [tr], [kr], [gr], [fr], [sr], [ps], [ks], [dw], [sw], [kw], [sp], [sm], [sn], [sk] yang dihasilkan dari keseluruhan data sebanyak 2 bunyi yaitu bunyi [br] dan [pr], dan data pola silabel yang terdapat dalam data ujaran lisan siswa tunarungu adalah sebanyak 149 pola silabel yang ditemukan. Jadi, secara keseluruhan data bunyi segmental yang dihasilkan oleh siswa tunarungu adalah 464 bunyi segmental termasuk pola silabel. 


\section{KESIMPULAN}

Berdasarkan hasil penelitian tentang analisis pelafalan bunyi segmental pada seorang siswa laki-laki yang mengalami ketunarunguan dapat disimpulkan sebagai berikut. Sebagian siswa tunarungu tersebut belum mampu mengujarkan bunyi - bunyi bahasa Indonesia yang baik berdasarkan penelitian yang sudah dilakukan bahwa masih ada beberapa bunyi segmental yang tidak dihasilkan. Bunyi segemental tersebut terdiri dari bunyi vokal, bunyi konsonan, bunyi diftong, bunyi kluster.

Berdasarkan hasil analisis pada data ujaran lisan dapat dikatakan bahwa dari keempat bunyi segmental tersebut terdapat tiga jenis bunyi segemental yang dapat dihasilkan oleh siswa tunarungu, yaitu bunyi vokal, bunyi konsonan, dan bunyi kluster, sedangkan bunyi diftong tidak dihasilkan. Sementara itu bunyi segemental yang sering keluar adalah bunyi vokal yaitu sebanyak 170 bunyi data yang dihasilkan. Diikuti dengan bunyi konsonan yang berjumlah 143 data yang dihasilkan.Terakhir adalah bunyi kluster yaitu sebanyak 2 data yang dihasilkan.Hal ini menyimpulkan bahwa siswa belum terbiasa berujar secara lisan, hal ini dikarenakan ketidakmampuan alat pendengaran yang berfungsi secara baik membuat siswa tidak bisa mendengar ujaran atau bunyi bahasa yang baik.

Berdasarkan pelafalanya siswa mampu melafalkan bunyi segmental pada beberapa posisi tertentu misalnya vokoid awal, vokoid tengah, vokoid akhir.Begitu juga dengan bunyi konsonan, diftong dan kluster. Dalam analisis ini telah ditemukan data secara keseluruhan dari setiap aspek bunyi segmental, yaitu 464 data dari 
keseluruhanya.464 data itu adalah jumlah data bunyi vokal, bunyi konsonan, bunyi diftong, bunyi kluster, dan pola silabel.

\section{UCAPAN TERIMA KASIH}

Terima kasih saya ucapkan kepada segala pihak yang telah memberikan dukungan dalam kelancaran penelitian ini.

\section{DAFTAR PUSTAKA}

Chaer, Abdul. (2013). Fonologi Bahasa Indonesia. Jakarta: Rineka Cipta.

Hildayani, R. (2008). Penanganan Anak Berkelainan. Jakarta: Universitas Terbuka.

Indriati, E. (2011). Kesulitan Berbicara \& Berbahasa pada Anak. Jakarta: Prenada.

Parera, J.D. (1983). Pengantar Linguistik Umum Bidang Fonetik dan Fonemik Seri D. Flores: Nusa Indah.

Muslich, Masnur. (2009). Fonologi Bahasa Indonesia. Jakarta: Bumi Aksara.

Sugiyono. (2003). Pedoman Penelitian Bahasa Lisan: Fonetik. Jakarta: Pusat Bahasa.

Utami, S. R. (2017). Pembelajaran Aspek Tata Bahasa dalam Buku Pelajaran Bahasa Indonesia. Aksis: Jurnal Pendidikan Bahasa dan Sastra Indonesia, 1(2). 189203. doi: doi.org/10.21009/AKSIS.010203 